\title{
Kernos
}

Revue internationale et pluridisciplinaire de religion grecque antique

$34 \mid 2021$

Varia

\section{Hermes und die Bürger. Der Hermeskult in den griechischen Poleis}

\section{Carmine Pisano}

\section{(2) OpenEdition \\ Journals}

Electronic version

URL: https://journals.openedition.org/kernos/3955

DOI: 10.4000/kernos.3955

ISSN: 2034-7871

\section{Publisher}

Centre international d'étude de la religion grecque antique

\section{Printed version}

Date of publication: 31 December 2021

Number of pages: 299-301

ISBN: 978-2-87562-305-8

ISSN: 0776-3824

\section{Electronic reference}

Carmine Pisano, "Hermes und die Bürger. Der Hermeskult in den griechischen Poleis", Kernos [Online], 34 | 2021, Online since 31 December 2021, connection on 15 March 2023. URL: http:// journals.openedition.org/kernos/3955 ; DOI: https://doi.org/10.4000/kernos.3955

This text was automatically generated on 15 March 2023.

All rights reserved 


\title{
Hermes und die Bürger. Der Hermeskult in den griechischen Poleis
}

\author{
Carmine Pisano
}

\section{REFERENCES}

Antje KUHLE, Hermes und die Bürger. Der Hermeskult in den griechischen Poleis, Stuttgart, Franz Steiner Verlag, 2020. 1 vol. 17,6 × 24,5 cm, 437 p. (Hermes - Einzelschrift, 119).

ISBN : 978-3-515-12809-4.

1 At the end of his book Configurations d'Hermès, Dominique Jaillard mentions Hermes' connection with the political sphere and, as an ideal continuation of his work, proposes the study of the roles and prerogatives of the god "dans les cités, entre marges et centres", "dans les structures et le fonctionnement même de la pólis, communauté des citoyens, territoire, institutions". ${ }^{1}$ Hermes und die Bürger by Antje Kuhle carries out this project. By abandoning the image of Hermes as an inferior divinity, this book enhances Hermes' political and social skills by considering him the god of the polis both as a territorial unity and as a community of citizens. The method adopted is that of institutional history. Hermes' functions and figures are analyzed in the light of political, social, religious and military institutions, focusing on practices (rites and cults) and both collective (the polis and its sub-groups) and individual (citizens) actors. The cult of Hermes, reconstructed thanks to votive inscriptions, public and private, and archaeological documentation, is put at the center of the investigation, rather than literary texts and mythical narratives. The analysis of epigraphic sources allows the A. to determine, from case to case, "von wem Hermes, wo, wie und warum verehrt wurde" (p. 25), highlighting the extent that the cult of the god was embedded in the daily life of the Greeks and how the public and individual interests of the cult complemented each other. In this sense Kuhle proposes combining the use of the 
historiographical models of "polis religion" and "personal religion" to demonstrate that "Hermes war nicht nur ein Gott der Polis, sondern vor allem ein Gott der Bürger" (p. 23).

2 The book follows the path of a hypothetical ancient visitor in an "ideale Stadt" (p. 27), from the borders to the center, illustrating places and contexts where he would have seen Hermes intervene in his function as protector of the public officials, community activities and city institutions. The expression "ideal city" must not be misunderstood. The city that forms the backdrop to the survey is ideal in the sense that it never existed as a unit but is no less concrete for this reason. In fact, it represents an "ideal" sum of the Greek cities in which Hermes was venerated, divided by territorial sections. The analysis of the cult topography of the god starts from the eschatia (border area) to arrive through the chora (extra-urban area) and the proastion (sub-urban area) to asty (urban area) and agora (political-economic center). In all these places the visit focuses on the institutions found there and on the link that unites them to Hermes: natural borders and border sanctuaries, border fortifications and ports, spatial and symbolic borders (eschatia); extra-urban sanctuaries, places of worship along roads and paths, processions and wedding parades (chora); necropolis and cult of the dead, gyms and agonal festivals (proastion); public offices, market and law (asty and agora).

The focus on institutions and their history allows Kuhle not only to reconstruct developments and changes in the cult of Hermes in a diachronic form (as in the case of the cult of Hermes Ayopaĩos in the context of the historical transformations of the agora), but also to underline the décalage between narratives and practices, and thereby to define a more concrete and complete image of the god, which extends and integrates the universe of mythical representations (as in the case of the analysis of Hermes

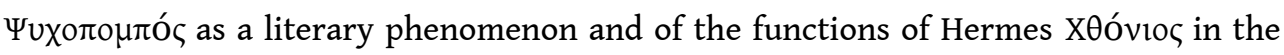
cult). The attention paid to the actors of the cult is a second, essential, instrument of historical-religious investigation. For example, Kuhle demonstrates that in Greek cities Hermes, as guarantor of the territory of the polis, is revered by categories responsible for protecting its borders, such as strategoi, members of the city army, epheboi. In the gymnasium, where he is associated with the training of young people and the crossing of symbolic boundaries (from adolescence to maturity, from the condition of ephebos to that of citizen-soldier), the god is honoured by educators and users of the institution, by winners of athletic and musical games, and by rulers. Personally, I am skeptical about interpreting of these forms of "individual agency" in cult contexts as "personal religion", since this definition risks casting the distorting shadow of modern categories onto the ancient world. Similarly, certain criticisms of the "polis religion" model (e.g. p. 348: "Wenn von der Polis die Rede ist, darf diese nicht als ein übergeordnetes, überindividuelles Machtmonopol missverstanden warden"; p. 349: "die Polis nicht nur ein abstraktes Gebilde, sondern vor allem ein Verband selbstständig handelnder Subjekte war, deren individuelle Bedürfnisse es im Sinne eines funktionierenden Zusammenlebens zu erfüllen galt") seem to me to construct a "polemical idol" that does not coincide with Christiane Sourvinou-Inwood's historiographical formulation and with the uses (however heterogeneous) that have been made of it. But this does not affect the value of the book. Kuhle's text constitutes the first systematic investigation of the cult of Hermes in relation to and within the poleis in a macro-historical perspective, which embraces the whole of the Greek world from the Archaic age to the end of the third century BC. For this reason, it will remain a point of reference for all subsequent studies on the subject. 


\section{NOTES}

1. D. JAILlARD, Configurations d'Hermès. Une "théogonie hermaïque», Liège, 2007 (Kernos, Suppl. 17), p. 240-241.

2. V. PIRENNE-DELFORGE, "Review of J. KINDT, Rethinking Greek Religion, Cambridge, 2012”, Asdiwal 11 (2016), p. 223.

\section{AUTHORS}

\section{CARMINE PISANO}

(Università di Napoli Federico II) 